\title{
Karakteristik Industri Tahu Di Kecamatan Pekalongan Kabupaten Lampung Timur
}

\section{Edi Haryono dan Dian Utami}

Masuk: 04092018 / Diterima: 28102018 / Dipublikasi: 31122018

(C) 2018 Fakultas Hukum dan IImu Sosial UNDIKSHA dan IGI

\begin{abstract}
The purpose of this study is to examine the characteristics of tofu industries in Pekalongan District, East Lampung Regency. The population used is 25 industries. The research method used is survey. The technique of collecting data uses observation, questionnaires, documentation and literature. Analysis of the data used is descriptive analysis. The results of the study show: 1) The average amount of capital used at one time tofu production is Rp. 283,200, 2) The origin of capital, namely own capital, 3) The average raw material at one production process is $33 \mathrm{Kg}$. comes from purchases in Pekalongan Market and Metro City Market, 5) The average number of workers is 2 people, 6) The origin of the workforce is $72.13 \%$ are family members, 7) The average expenditure for purchasing wood and diesel fuel a month namely Rp. 748,800. 8) Purchases of wood fuel come from Sidodadi, Pekalongan, Adijaya, and Tulusrejo Villages. The purchase of diesel fuel comes from Pertamina and Warung, 9) The average production of tofu is one production as much as 938 pieces, 10) Transportation used to transport soybeans is trucks and motorbikes. Marketing of tofu products using motorbikes, 11) The marketing system is sold by entrepreneurs and bought by traders. The marketing area for tofu production is the Pekalongan District market and Metro City Market, 12) The average income of the tofu industry is Rp. 1799600 per month.
\end{abstract}

Keywords: Industrial Characteristics; Tofu Industry

\begin{abstract}
Abstrak Tujuan penelitian ini mengkaji karakteristik industri tahu di Kecamatan Pekalongan Kabupaten Lampung Timur. Populasi yang digunakan sebanyak 25 industri. Metode penelitian yang digunakan yaitu survei. Teknik pengumpulan data menggunakan observasi, kuesioner, dokumentasi dan kepustakaan. Analisis data yang digunakan yaitu Analisis deskriptif. Hasil penelitian menunjukkan:1) Besar rata-rata modal yang digunakan pada sekali produksi tahu Rp 283.200, 2) Asal modal yaitu modal sendiri, 3) Rata-rata bahan mentah pada satu kali proses produksi adalah 33 $\mathrm{Kg}$, 4) Bahan mentah yang digunakan berasal dari pembelian di Pasar Pekalongan dan Pasar Kota Metro, 5) Rata-rata jumlah tenaga kerja adalah 2 orang, 6) Asal tenaga kerja yaitu $72,13 \%$ merupakan anggota keluarga, 7) Rata-rata pengeluaran pembelian bahan bakar kayu dan solar sebulan yaitu Rp 748.800 , 8) Pembelian bahan bakar kayu berasal dari Desa Sidodadi, Pekalongan, Adijaya, dan Tulusrejo. Pembelian bahan bakar solar berasal dari Pertamina dan Warung, 9) Ratarata produksi tahu setiap satu kali produksi sebanyak 938 buah, 10) Transportasi yang digunakan untuk mengangkut kedelai adalah truk dan sepeda motor. Pemasaran hasil produksi tahu menggunakan sepeda motor, 11) Sistem pemasaran adalah dengan cara dijual sendiri oleh pengusaha dan dibeli oleh pedagang. Daerah pemasaran produksi tahu adalah pasar Kecamatan Pekalongan dan Pasar Kota Metro, 12) Rata-rata pendapatan industri tahu perbulan sebesar Rp 1799600.
\end{abstract}

Kata kunci: Karakteristik Industri; Industri Tahu

\section{Pendahuluan}

Salah satu usaha untuk meningkatkan kesejahteraan masyarakat adalah dengan membangun suatu industri, baik industri besar, industri menengah, industri kecil mapun industri

Edy Haryono dan Dian Utami

Fakultas Keguruan dan IImu Pendidikan

Universitas Lampung

rumah tangga, dengan berbagai macam produk yang dihasilkannya untuk memenuhi kebutuhan hidup masyarakat. Menurut Kartasapoetra (1989:6) industri adalah kegiatan ekonomi yang mengolah bahan mentah, bahan baku, barang setengah jadi dan atau barang jadi menjadi barang dengan nilai yang lebih tinggi lagi penggunaannya, termasuk dhian.ramick@gmail.com, 
kegiatan rancang bangun industri dan perekayasaan industri.

Tujuan dari didirikannya suatu industri adalah untuk memperoleh keuntungan guna mencukupi kebutuhan pengusaha dan masyarakat. Seperti dikemukakan oleh Bintarto (1977: 88) bahwa Industrialisasi di tujukan untuk: 1) Menaikkan taraf hidup, 2) Menghambat pertambahan penduduk, 3) Memudahkan penghidupan.

Dari tujuan tersebut dapat disimpulkan bahwa kegiatan industri dapat meningkatkan penghasilan pengusaha secara rutin bila dibandingkan dengan penghasilan dalam bidang pertanian, karena usaha industri dapat diproduksi dan di pasarkan tiap hari, sedangkan usaha di bidang pertanian baru dapat diambil hasilnya setelah panen dengan waktu yang lebih lama dari pada usaha suatu industri. Selain itu pemerintah sangat mendukung pembangunan industri besar maupun industri kecil yaitu pemerintah menganut kebijaksanaan " berdiri di atas dua kaki" (walk on two legs) dalam mengembangkan industri, yaitu disatu pihak meneruskan kebijaksanaan yang mendorong tumbuhnya industriindustri besar-besaran, namum sektor industri kecil tradisional tidak dilupakan (Rahardjo, 1986: 120).

Geografi industri adalah aktivitas manusia dalam proses produksi suatu barang di suatu lokasi permukaan bumi untuk memenuhi kebutuhan hidup manusia. Menurut Johnston (1981: 164) Industrial geography is the spatial aragement of industrial activity: Industrial Geography is a subfield of economic geography, and deal urth manufacturing or secondary activity. Artinya: bahwa geografi industri adalah studi tentang susunan keruangan dari aktivitas industri, dan geografi industri merupakan bagian (sub) dari bidang ekonomi, dan berhubungan dengan pabrik atau aktivitas sekunder.
Tahu merupakan makanan yang dapat dikonsumsi oleh penduduk, baik yang kurang mampu ekonominya sampai masyarakat mampu ekonominya. Selain itu pemanfaatan tahu dapat disajikan dalam berbagai acara di lingkungan masyarakat, sebagai bahan sayur di rumah makan, dan untuk bahan aneka makanan camilan di warung. Hal ini yang menjadikan tahu banyak diminati masyarakat.

Industri tahu sebagian besar diusahakan oleh masyarakat pedesaan dan untuk membuatnya dengan menggunakan alat-alat tradisional maupun modern. Tahu merupakan salah satu jenis makanan nabati yang berprotein terbuat dari sari kacang kedelai yang dipadatkan.

Kegiatan dalam industri tahu ini juga dilakukan oleh penduduk di Wilayah Kecamatan Pekalongan Kabupaten Lampung Timur. Tahu tersebut merupakan makanan yang dapat dimakan langsung maupun sebagai bahan sayur yang dikonsumsi oleh masyarakat yang berpenghasilan rendah, menengah ataupun berpenghasilan tinggi.

Wilayah Kecamatan Pekalongan terdiri dari 12 desa yang sebagian besar bermata pencaharian di bidang pertanian. Berdasarkan prasurvei 17 februari 2017, di wilayah Kecamatan Pekalongan terdapat 25 industri tahu yang berlokasi di desa-desa. Umumnya produksi tahu di Pekalongan dipasarkan di pasar Kecamatan Pekalongan, dan sekitarnya. Ada pula pembelian tahu yang mendatangi langsung ke tempat industri seperti orang yang pulang dari bekerja di kantor kemudian mampir membeli tahu untuk dibawa pulang ke rumahnya, baik yang berasal dari lingkungan setempat maupun dari tempat lain. Tahu yang diproduksi merupakan tahu murni atau tahu asli yang tidak diberi bahan kimia, sehingga bisa dikonsumsi langsung baik tahu yang masih berwarna putih maupun 
yang sudah digoreng. Limbah tahu yang berupa ampas kedelai juga dapat dimanfaatkan untuk dibuat tempe warna putih dan warna kuning cara membuatnya melalui proses fermentasi. Ampas tahu yang sudah diproses melalui fermentasi ini digunakan sebagai bahan sayur maupun bahan makanan camilan setelah digoreng. Ampas tahu tersebut tanpa diolah dapat digunakan sebagai pakan hewan ternak sapi, kambing dan unggas.

Adapun industri tahu yang ada di wilayah Kecamatan Pekalongan merupakan industri yang tahan terhadap tantangan berusaha, karena pada waktu terjadi krisis moneter tahun 1997 industri tahu tetap stabil dan berproduksi sampai sekarang. Hal ini di sebabkan oleh beberapa faktor pendukung berdirinya suatu industri. Dari kacamata geografi, industri sebagai suatu sistem, merupakan perpaduan subsistem fisis dengan subsistem manusia. Subsistem fisis yang mendukung pertumbuhan dan perkembangan industri yaitu komponenkomponen lahan, bahan mentah atau bahan baku, sumberdaya energi, iklim dengan segala proses alamiahnya. Sedangkan subsistem manusia yang mempengaruhi pertumbuhan dan perkembangan industri meliputi komponen-komponen tenaga kerja, kemampuan teknologi, tradisi, keadaan politik, keadaan pemerintahan, transportasi dan komunikasi, konsumen dan pasar, dan lain-lain sebagainya (Nursid Sumaatmadja,1988: 179-180).

Wilayah Kecamatan Pekalongan tidak ada tanaman kedelai sebagai bahan dasar pembuatan tahu, namun sampai sekarang industri tahu tetap jalan dan berproduksi terus. Lahan di wilayah Kecamatan Pekalongan adalah pertanian sawah irigasi yang cocok ditanami padi, palawija, dan sayuran dan tidak ada yang menamam kacang kedelai. Hal inilah yang menarik walaupun penggunaan lahan di lingkungan Kecamatan Pekalongan tidak ada tanaman kedelai, tetapi industri tahu tetap terus berproduksi.

Aktivitas pembuatan tahu di Wilayah Pekalongan ini mungkin dapat didukung oleh faktor-faktor geografi, baik faktor fisis maupun faktor non fisis. Faktor letak dan jarak merupakan faktor fisis yang dapat diperhitungkan untuk memproduksi tahu agar produksi itu mudah dapat dipasarkan. Faktor non fisis juga dapat diperhitungkan dalam memproduksi tahu agar dapat habis dikonsumsi oleh masyarakat.

Untuk mendirikan industri tahu diperlukan lokasi, bahan mentah, modal, tenaga kerja baik tenaga manusia maupun tenaga mesin, transportasi, pemasaran dan air untuk memudahkan dalam proses pengolahan. Geografi Industri sebagai bagian dari geografi ekonomi antara lain menstudi lokasi, sedang faktor lokasi ini berkaitan dengan wilayah bahan mentah, pasaran, sumber suplai, tenaga kerja, bahan bakar, dan jalur transportasi, ... (Daldjoeni, 1992: 167).

Industri tahu juga dapat membantu memberikan penghasilan kepada para pekerjanya dan dapat menyerap tenaga kerja yang ada di sekitarnya, maupun di luar lingkungannya. Maka dari itu masalah ini penting untuk diteliti karena untuk memberikan daya tarik bagi tenaga produktif yang mau mengusahakan maupun bekerja pada bidang industri tahu guna menambah penghasilan. Secara umum untuk mendirikan suatu industri diperlukan persyaratan modal, bahan mentah, tenaga kerja, bahan bakar, transportasi (aksesibilitas), dan pemasaran.

Berdasarkan uraian tersebut dapat dijelaskan bahwa adanya industri tahu di Wilayah Pekalongan perlu dikembangkan agar dapat menciptakan lapangan kerja, menyerap tenaga kerja, memberikan kesempatan berusaha, menambah pendapatan dan meningkatan taraf hidup masyarakat. 


\section{Metode}

Metode penelitian yang digunakan dalam penelitian ini adalah metode survei, yaitu penyelidikan yang diadakan untuk memperoleh fakta-fakta dari gejala-gejala yang ada dan mencari keteranganketerangan secara faktual, baik tentang institusi sosial, ekonomi, atau politik dari suatu kelompok ataupun suatu daerah. Metode survei salah satu cara yang utama untuk mengumpulkan data primer bila data sekunder dianggap belum cukup lengkap untuk menjawab sesuatu pertanyaan. Tujuan penelitian survei adalah untuk mengetahui gambaran umum karakteristik dari populasi. Populasi dalam penelitian ini adalah industri tahu yang ada di Wilayah Pekalongan Keca-matan Pekalongan sebanyak 25 industri tahu. Teknik pengumpulan data yaitu menggunakan teknil observasi, kuesioner, dokumentasi, dan kepustakaan. analisis data yang digunakan adalah Analisis Persentase
Tabel Frekuensi. Frekuensi adalah jumlah pemunculan karakteristik yang sama dari hasil pengamatan. Jika data disusun dalam tabel yang mencakup kelas beserta frekuensinya, tabel tersebut dinamakan tabel distribusi frekuensi sederhana. Data yang sudah terkumpul dikoding dan ditabulasikan ke dalam tabel kemudian dipersentasekan. Setelah dihitung persentasenya kemudian di deskripsikan untuk ditarik kesimpulan.

\section{Hasil dan Pembahasan Modal}

Modal produksi atau modal bergerak igunakan untuk pembelian kedelai, kayu bakar, minyak solar dapat dicukupi sendiri tanpa meminjam dari Bank maupun Koperasi. Untuk lebih jelasnya modal yang digunakan untuk proses produksi tahu dapat dilihat pada Tabel 1.

Tabel 1. Modal Sekali Produksi Tahu Di Kecamatan Pekalongan Tahun 2017

\begin{tabular}{cccc}
\hline No & Modal (Rp) & $\begin{array}{c}\text { Jumlah } \\
\text { Responden }\end{array}$ & Persentase (\%) \\
\hline $\mathbf{1}$ & $<2500000$ & 6 & 24 \\
$\mathbf{2}$ & $2500000-3500000$ & 17 & 68 \\
$\mathbf{3}$ & $>3500000$ & 2 & 8 \\
& Jumlah & 25 & 100 \\
\hline
\end{tabular}

Sumber : Data Penelitian, 2018

Dari Tabel 2 bahwa rentang modal terbanyak adalah $\mathrm{Rp} 2500000$ - Rp 3500000 sebanyak 17 responden (68\%), karena pemasaran tahu hanya pasar kecamatan sehingga bila ditambah modal khawatir tahunya tidak habis terjual. Modal terkecil satu produksi tahu adalah $\mathrm{Rp}$ 1400000 dan modal terbesar sekali produksi tahu adalah Rp 4500000. Ratarata modal yang digunakan untuk sekali produksi tahu adalah Rp 283200.

\section{Sumber Modal}

Industri tahu membutuhkan modal, baik modal tetap maupun modal bergerak atau modal produksi bagi pelaku industri atau responden penelitian menyatakan bahwa semua modal industri tersebut $100 \%$ berasal dari modal sendiri (Sumber : Data Penelitian). Jadi seluruh responden atau 25 pengusaha industri tahu modalnya berasal dari modal sendiri, karena para responden tersebut sudah mempersiapkan diri sebelumnya.

\section{Jumlah Rata-rata bahan mentah}

Bahan mentah yang digunakan untuk membuat industri tahu adalah kedelai. Adapun jenis kedelai yang digunakan untuk membuat tahu adalah jenis kedelai impor, karena kedelai ini lebih besar dari pada kedelai dalam negeri. Pengusaha industri tahu me-milih kedelai impor karena kedelai tersebut ukurannya merata 
dan lebih besar dari kedelai lokal serta selalu tersedia di pasar-pasar, baik pasar di tingkat kecamatan maupun pasar kabupaten.

Ketersediaan kedelai di pasarpasar atau di toko-toko inilah yang sangat baik untuk proses berlangsungnya industri tahu sehingga tidak terjadi stagnasi dalam proses industri tahu. Untuk lebih jelasnya mengenai kedelai yang digunakan untuk sekali proses produksi dapat dilihat pada Tabel 3.

Tabel 3. Bahan Mentah (Kedelai) Yang Digunakan Sekali Produksi Tahu Di Kecamatan Pekalongan Tahun 2017

\begin{tabular}{cccc}
\hline No & $\begin{array}{c}\text { Bahan Mentah } \\
\text { (kedelai) } \\
\text { /kg }\end{array}$ & $\begin{array}{c}\text { Jumlah } \\
\text { Responden }\end{array}$ & Persentase (\%) \\
\hline $\mathbf{1}$ & $10-39$ & 18 & 72 \\
$\mathbf{2}$ & $40-69$ & 5 & 20 \\
$\mathbf{3}$ & $70-100$ & 2 & 8 \\
& Jumlah & 25 & 100 \\
\hline
\end{tabular}

Sumber : Data Penelitian, 2018

Dari Tabel 3 dapat diketahui bahwa kedelai yang digunakan dalam sekali produksi yang terbanyak adalah rentang antara $10 \mathrm{~kg}$ - $39 \mathrm{~kg}$ sebanyak 18 industri (72\%), hal ini disebabkan bila diperbanyak kedelai yang digiling dikhawatirkan tidak terjual habis karena pemasarannya hanya pasar lokal tingkat kecamatan

Adapun kedelai yang paling sedikit diproduksi untuk dibuat tahu di Kecamatan Pekalongan adalah $10 \mathrm{Kg}$ dan yang terbanyak adalah $100 \mathrm{Kg}$, sedangkan rata-rata kedelai yang digunakan untuk membuat tahu dalam satu kali proses prokduksi adalah $32,96 \mathrm{Kg}$ atau dibulatkan $33 \mathrm{Kg}$.

\section{Asal bahan mentah}

Bahan mentah (kedelai) yang diigunakan untuk proses produksi tahu di wilayah Kecamatan Pekalongan dari datangkan dari luar negeri yaitu Amerika Serikat. Oleh karena itu lancarnya pedagang Indonesia mengimpor besar ini mempengaruhi kelancaran industri makanan yang berasal dari kedelai. Maka dari itu asal bahan mentah (kedelai) yang dimaksudkan adalah tempat pembelian kedelai di pasar maupun ditempat lain. Untuk lebih jelasnya asal pembelian kedelai dapat dilihat pada Tabel 4.

Tabel 4. Asal Bahan Mentah (Kedelai) Yang Digunakan Sekali Produksi Tahu Di Kecamatan Pekalongan Tahun 2017

\begin{tabular}{cccc}
\hline No & $\begin{array}{c}\text { Tempat Pembelian } \\
\text { Kedelai }\end{array}$ & Jumlah Responden & Persentase (\%) \\
\hline $\mathbf{1}$ & Pasar Metro & 6 & 24 \\
$\mathbf{2}$ & Pasar Pekalongan & 19 & 76 \\
& Jumlah & 25 & 100 \\
\hline
\end{tabular}

Sumber : Data Penelitian, 2018

Dari Tabel 4 tersebut dapat diketahui bahwa asal pembelian kedelai untuk proses produksi tahu adalah di Kecamatan Pekalongan berasal dari pasar Pekalongan, hal ini disebabkan karena pemasaran tahu terbanyak adalah di Pasar Pekalongan. Maka dari itu pengusaha tahu selain menjual tahu di Pasar Pekalongan sekaligus bisa membeli kedelai untuk proses produksi di hari berikutnya. Jadi ada keuntungan bagi pengusaha tahu, yaitu selain menghemat tenaga juga menghemat waktu. Pembelian kedelai seperti ini karena 
kedelai yang diproduksi tidak banyak sehingga kedelai bisa diangkut dengan mengunakan sepeda motor.

Selain itu ada pembelian kedelai di pasar Metro sebanyak 6 orang pengusaha industri tahu. Ke enam pengusaha ini pembelian kedelai cukup banyak dari pengusaha industri tahu lainnya, maka pembelian kedelai dilaksanakan di pasar Kota Metro. Pembeliannya cukup mudah karena hanya dengan melalui telepon ke toko kedelai di Metro, maka pihak toko kedelai di Metro yang mengirim ke kedele ke tempat industri tahu yang memesannya. Ini berarti lebih mudah membelinya tidak perlu mengangkut sendiri kedelainya.

\section{Jumlah tenaga kerja}

Untuk dapat berlangsungnya usaha industri tahu tidak dapat dilupakan yaitu pentingnya tenaga kerja yang memproses kedelai menjadi tahu yang siap di pasarkan. Tenaga kerja ini bisa di datangkan dari daerah lain dan bisa juga dari keluarganya sendiri. Tenaga kerja dalam pembuatan tahu sangat diperlukan tenaganya, karena ada unsur mengangkat kedelai untuk digiling, memindahkan kedelai halus ke tempat air mendidih yang masih panas, memindahkan kedelai halus yang masih panas ke tempat penyaringan, memindahkan ampas ke tempat penampungan, mengangkat sari kedelai yang sudah menggumpal ke tempat percetakan tahu, mengangkat batu ukuran $10 \mathrm{~kg}$ untuk menindih sari kedelai ditempat papan pencetak tahu, memindahkan tahu yang sudah jadi ketempat rak-rak tahu yang siap dipotong sesuai ukuran. Oleh karena itu tenaga kerja yang diperlukan pada industri tahu harus mempunyai tenaga kerja yang optimum tenaganya. Mengenai jumlah tenaga kerja yang diperlukan pada industri tahu di Kecamatan Pekalongan dapat dilihat pada Tabel 5.

Tabel 5. Jumlah Tenaga Kerja Yang Digunakan Dalam Produksi Tahu Di Kecamatan Pekalongan Tahun 2017

\begin{tabular}{cccc}
\hline No & $\begin{array}{c}\text { Jumlah Tenaga } \\
\text { Kerja (orang) }\end{array}$ & Responden & Persentase (\%) \\
\hline $\mathbf{1}$ & 2 & 22 & 88 \\
$\mathbf{2}$ & 5 & 2 & 8 \\
$\mathbf{3}$ & 7 & 1 & 4 \\
& Jumlah & 25 & 100 \\
\hline
\end{tabular}

Sumber : Data Penelitian, 2018

Industri tahu yang paling banyak menggunakan tenaga kerja adalah 7 orang hanya 1 industri, hal ini disebabkan bahan baku/kedelai yang digiling cukup banyak yaitu $100 \mathrm{~kg}$, dan pemasaran tahu lebih dari satu tempat. Responden yang terbanyak menggunakan tenaga kerja adalah 22 pengusaha (88\%) sebanyak 2 orang, hal ini karena pemasaran tahu hanya di pasar Pekalongan.

\section{Asal tenaga kerja}

Dalam mengelola usaha industri tahu walaupun persyaratan lain sudah tercukupi, maka tenaga kerja sangat diperlukan. Untuk memperoleh tenaga kerja yang handal yang dapat membuat tahu berkualitas memerlukan kepandaian dalam mengatur semua proses baik kualitas dan kebersihannya. Untuk memperoleh tenaga kerja dapat diambil dari daerah lain maupun dari dalam keluarga. Mengenai asal tenaga kerja pada industri tahu di Kecamatan Pekalongan dapat di lihat pada Tabel 6. 
Tabel 6. Asal Tenaga Kerja Yang Digunakan Dalam Produksi Tahu

Di Kecamatan Pekalongan Tahun 2017

\begin{tabular}{ccccc}
\hline No & Asal Tenaga Kerja & $\begin{array}{c}\text { Jumlah } \\
\text { Tenaga } \\
\text { Kerja }\end{array}$ & $\begin{array}{c}\text { Responde } \\
\mathbf{n}\end{array}$ & Persentase\% \\
\hline $\mathbf{1}$ & Dari luar keluarga & 17 & 3 & 27,87 \\
$\mathbf{2}$ & Dari dalam keluarga & 44 & 22 & 72,13 \\
& Jumlah & 61 & 25 & 100,00 \\
\hline
\end{tabular}

Sumber: Data Penelitian, 2018

Dari tabel 6 dapat di simpulkan bahwa 44 orang $(72,13 \%)$ tenaga kerja pada industri tahu di Kecamatan Pekalongan berasal dari dalam keluarga, karena dengan pertimbangan ada anggota keluarga yang menganggur dan mudah untuk mengatasinya, dan jumlah kedelai yang digiling tidak banyak. Sebanyak 17 orang $(27,87 \%)$ tenaga kerja pada industri tahu di Kecamatan Pekalongan berasal dari luar keluarga karena kedelai yang digiling cukup banyak sehingga memang memerlukan tenaga kerja lebih dari dua orang, untuk mempercepat proses produksi.

\section{Bahan bakar}

Untuk proses produksi tahu dalam suatu industri memerlukan bahan bakar. Bahan bakar ada dua macam yaitu bahan bakar solar untuk menggiling kedelai dan bahan bakar kayu untuk memanaskan sari kedelai. Tanpa kedua bahan bakar ini sulit untuk melaksanakan proses produksi tahu. Maka dari itu kayu bakar merupakan salah satu sumber panas yang penting dalam proses produksi tahu. Oleh karena itu untuk memperoleh kayu bakar diperlukan biaya untuk membelinya. Untuk lebih jelasnya mengenai pengeluaran biaya untuk bahan bakar solar dapat dilihat pada Tabel 7.

Tabel 7. Pengeluaran Pembelian Solar Dan Kayu Bakar Untuk Proses Produksi Tahu Sebulan Di Kecamatan Pekalongan Tahun 2017

\begin{tabular}{ccccccc}
\hline No & $\begin{array}{c}\text { Biaya Bahan } \\
\text { Bakar solar (Rp) }\end{array}$ & $\begin{array}{c}\text { Respon } \\
\text { den }\end{array}$ & $\begin{array}{c}\text { Persentas } \\
\text { e(\%) }\end{array}$ & $\begin{array}{c}\text { Biaya Kayu } \\
\text { Bakar (Rp) }\end{array}$ & $\begin{array}{c}\text { Respon } \\
\text { den }\end{array}$ & $\begin{array}{c}\text { Persentas } \\
\text { e (\%) }\end{array}$ \\
\hline $\mathbf{1}$ & $<240000$ & 11 & 44 & $<230000$ & 9 & 36 \\
$\mathbf{2}$ & $240000-370000$ & 11 & 44 & $23000-360000$ & 6 & 24 \\
$\mathbf{3}$ & $>370000$ & 3 & 12 & $>360000$ & 10 & 40 \\
& $\begin{array}{l}\text { Jumlah } \\
\end{array}$ & 25 & 100 & & 25 & 100 \\
\hline
\end{tabular}

Sumber: Data Penelitian, 2018

Dari Tabel 7 dapat diketahui bahwa untuk membuat tahu diperlukan 2 macam bahan bakar yaitu solar untuk keperluan menggiling kedelai dan kayu bakar diprlukan untuk merebus sari kedelai. Berdasarkan rekap data pada lampiran 2 tentang biaya pengeluaran untuk pembelian solar dan kayu bakar perbulan terendah adalah solar Rp 110000 dan kayu bakar 100000. Jadi keduanya sebesar $\mathrm{Rp} 210000$. Pengeluaran tertinggi pembelian solar Rp 500000 dan kayu bakar Rp 4000000 . Jadi pengeluaran tertinggi keduanya sebesar 
Rp 4500000. Sedangkan pengeluaran rata-rata untuk pembelian solar dan kayu bakar adalah pembelian solar Rp 254800 dan kayu bakar Rp 494000. Jadi pengeluaran rata-rata solar dan kayu bakar Rp 748800.

Tempat pembelian bahan bakar solar dan Bakar Kayu

Sudah diketahui bahwa pembelian solar untuk proses produksi tahu adalah untuk menghidupkan mesin penggiling kedelai. Menggiling atau menghaluskan kedelai dengan mengunakan mesin jauh lebih cepat dari pada menggiling kedelai secara manusla yaitu dengan batu giling yang dikerjakan dengan tenaga manusia. Adapun tempat pembelian solar atau asal pembelian solar oleh pengusaha industri tahu dapat dilihat pada Tabel 8.

Tabel 8. Asal Pembelian Solar Untuk Untuk Produksi Tahu

Di Kecamatan Pekalongan Tahun 2017

\begin{tabular}{cccc}
\hline No & $\begin{array}{c}\text { Asal /Tempat } \\
\text { Pembelian Solar }\end{array}$ & $\begin{array}{c}\text { Responden } \\
\text { (orang) }\end{array}$ & Persentase (\%) \\
\hline $\mathbf{1}$ & Pertamina & 15 & 60 \\
$\mathbf{2}$ & Warung & 10 & 40 \\
& Jumlah & 25 & 100 \\
\hline
\end{tabular}

Sumber: Data penelitian, 2018

Dari tabel 8 dapat diketahui bahwa tempat asal pembelian bahan bakar solar untuk proses produksi tahu di wilayah Kecamatan Pekalongan adalah 15 orang $(60 \%)$ adalah di Pertamina, karena Pertamina tersebut dekat lokasinya yaitu 500 meter dari Pasar Kecamatan Pekalongan.
Untuk membuat produksi tahu dalam suatu industri diperlukan bahan bakar kayu (kayu bakar) untuk keperluan proses merebus sari kedelai maupun untuk keperluan menggoreng tahu. Adapun asal pembelian bahan bakar kayu untuk industry tahu di Kecamatan pekalongan dalat dilihat pada Tabel 9.

Tabel 9. Asal Pembelian Kayu Bakar Untuk Untuk Produksi Tahu Di Kecamatan Pekalongan Tahun 2017

\begin{tabular}{clcc}
\hline No & $\begin{array}{c}\text { Asal /Tempat } \\
\text { Pembelian Kayu } \\
\text { Bakar }\end{array}$ & $\begin{array}{c}\text { Responden } \\
\text { (orang) }\end{array}$ & Persentase\% \\
\hline $\mathbf{1}$ & Desa Sidodadi & 18 & 72 \\
$\mathbf{2}$ & Daerah sekitarnya & 2 & 8 \\
$\mathbf{3}$ & Pekalongan & 1 & 4 \\
$\mathbf{4 .}$ & Adi Jaya & 2 & 8 \\
$\mathbf{5}$ & Tulusrejo & 1 & 4 \\
& Jumlah & 25 & 100 \\
\hline
\end{tabular}

Sumber: Data Penelitian, 2018 
Dari Tabel 9 dapat diketahui bahwa tempat /asal pembelian kayu bakar yang terbanyak adalah pembelian terbanyak adalah di Sidodadi yaitu 18 pengusaha (71\%) karena lokasinya dekat dengan tempat industri tahu. Adapun kayu bakar yang digunakan untuk proses produksi tahu bermacam-macam yaitu ada rantingranting kayu, kayu limbah dari penebang kayu.

\section{Produksi Tahu}

Industri tahu di Kecamatan Pekalongan memproduksi tahu dalam bentuk bijian persegi empat dengan jenisnya tahu mentah berwarna putih. Ukuran tahu menurut permintaan pasar yang paling banyak adalah ukuran $5 \mathrm{~cm} \times 3 \mathrm{~cm} \times 2$ $\mathrm{cm}$. Tahu dengan ukuran ini harga tahu dapat terjangkau oleh semua lapisan masyarakat, karena penjualannya pun relatif murah yakni $\mathrm{Rp} 400$ per buah. Untuk melihat jumlah produksi tahu sebulan Kecamatan Srandakan dan Kecamatan Kasihan dapat dilihat pada Tabel 10.

Tabel 10. Produksi tahu sebulan di Kecamatan Pekalongan tahun 2017

\begin{tabular}{cccc}
\hline No & $\begin{array}{c}\text { Produksi Tahu } \\
\text { (biji) }\end{array}$ & Responden & Persentase (\%) \\
\hline $\mathbf{1}$ & $<30000$ & 18 & 72 \\
$\mathbf{2}$ & $30000-60000$ & 5 & 20 \\
$\mathbf{3}$ & $>60000$ & 2 & 8 \\
& Jumlah & 25 & 100 \\
\hline
\end{tabular}

Sumber: Data Penelitian, 2018

Dari tabel 10 dapat diketahui bahwa produksi tahu terbanyak adalah kurang dari 30000 biji per bulan yaitu sebanyak 18 responden industri tahu.

\section{Transportasi}

Transportasi yang digunakan untuk transportasi input dalam hal ini adalah transportasi yang digunakan untuk mengangkut kedelai dari pasar ke tempat industri tahu. Transportasi input yang digunakan oleh pengusaha industri tahu di Kecamatan Pekalongan adalah, sepeda motor milik pribadi. Untuk lebih jelasnya transportasi yang digunakan industri tahu di Kecamatan Pekalongan dapat dilihat pada Tabel 11.

Tabel 11. Transportasi Untuk Mengangkut Kedelai Dari Toko Ke Lokasi Industri Tahu Di Kecamatan Pekalongan Tahun 2017

\begin{tabular}{clcc}
\hline No & $\begin{array}{l}\text { Transportasi Pembelian } \\
\text { Kedelai }\end{array}$ & Responden & Persentase (\%) \\
\hline $\mathbf{1}$ & Mobil toko kedelai kota Metro & 10 & 40 \\
$\mathbf{2}$ & Sepeda motor & 15 & 60 \\
$\quad$ Jumlah & 25 & 100 \\
\hline
\end{tabular}

Sumber: Data Penelitian, 2018

Dari Tabel 11 dapat diketahui bahwa transportasi untuk mengangkut kedelai dari took kedelai sampai ke tempat industri yang terbanyak adalah 
dengan mgnggunakan sepeda motor yaitu 15 pengusaha (60\%). Para pengusaha industri tahu menggunakan sepeda motor untuk mengangkut kedelai ke tempat industri tahu karena setelah selesai memasarkan tahu langsung membeli kedelai di pasar, hal ini lebih effisien waktu dan tenaga.

Sebanyak 10 pengusaha tahu (40\%) yang memerlukan kedelai cukup banyak untuk mendapatkan kedelai dapat langsung ke toko kedelai dan dapat pula menghubungi melalui telpon kemudian oleh pihak toko kedelai diantar ke alamat pemesan menggunakan mobil.

Transportasi unrtuk pemasaran tahu dari tempat industri ke pasar-pasar baik dijual sendiri maupun dijual oleh pedagang, bahwa sebanyak 25 pengusaha tahu (100\%) alat transportasi untuk pemasaran tahu menggunakan sepeda motor. Adapun cara mengangkut tahu tersebut adalah sepeda motor diberi tempat khusus diletakkan di sebelah kanan dan kiri jok yang terbuat dari kayu, besi atau kain terpal.

\section{Sistem Pemasaran Tahu}

Sistem pemasaran tahu di wilayah Kecamatan Pekalongan bermacam-macam, ada yang dijual sendiri ke pasar, ada yang dibeli oleh pedagang untuk dijual.namun ada pula pemasaran yang tidak terduga yaitu kadang-kadang ada konsumen yang membeli sendiri ke tempat industri tahu, namun ini tidak mempengaruhi sistem pemasaran tahu yang seperti biasanya. Untuk lebih jelasnya sistem pemasaran tahu di Kecamatan Pekalongan dapat dilihat pada Tabel 12.

Tabel 12. Sistem Pemasaran Tahu Di Kecamatan Pekalongan Tahun 2017

\begin{tabular}{cccc}
\hline No & Sistem Pemasaran Tahu & Responden & $\%$ \\
\hline $\mathbf{1}$ & Dijual sendiri oleh pengusaha tahu & 18 & 72 \\
$\mathbf{2}$ & Dibeli oleh pedagang & 7 & 28 \\
& Jumlah & 25 & 100 \\
\hline
\end{tabular}

Sumber: Data Penelitian, 2018

Dari Tabel 12 dapat diketahui bahwa sistem pemasaran tahu yang dijual sendiri oleh pengusaha tahu sebanyak 18 orang (72\%), hal ini terjadi karena tahu yang diproduksi tidak banyak dan pemasarannya di pasar lokal. Sedangkan tahu yang dibeli oleh pedagang ada 7 orang $(28 \%)$ karena tahu yang diproduksi lebih banyak maka pemasarannya dibeli oleh pedagang untuk dijual ke pasar.

\section{Pendapatan}

Tujuan mendirikan industri tahu oleh pengusaha tahu adalah untuk memperoleh pendapatan guna memenuhi kebutuhan hidup diri sendiri dan keluarga. Untuk lebih jelasnya pendapatan rata-rata perbulan pengusaha industri tahu di Kecamatan Pekalongan dapat dilihat pada Tabel 13.

Tabel 13. Pendapatan Pengusaha Tahu Sebulan Di Kecamatan Pekalongan Tahun 2017

\begin{tabular}{cccc}
\hline No & Pendapatan (Rp) & Responden & Persentase (\%) \\
\hline $\mathbf{1}$ & $<1420000$ & 8 & 32 \\
$\mathbf{2}$ & $1420000-2720000$ & 12 & 48 \\
\hline
\end{tabular}


Jumlah

5

100

Sumber: Data Penelitian, 2018 
Dari Tabel 13 diketahui bahwa rentang penghasilan terbanyak adalah Rp 1420000 - Rp 2720000 sebanyak 12 pengusaha. Pendapatan industri tahu terendah perbulan di Kecamatan Pekalongan adalah Rp 120000, karena pengelolanya adalah seorang wanita single parent yang lemah sehingga kemampuannya sangat terbatas untuk berwiraswasta. Pendapatan tertinggi sebesar Rp 4000000, karena pengelolanya seorang bapak yang masih berumur produktif dan bisa mengatur dalam berwiraswasta. Pendapatan ratarata pengusaha industri tahu di Kecamatan Pekalongan adalah sebesar Rp 1799600.

\section{Kesimpulan}

1) Besarnya rata-rata modal yang digunakan pada proses sekali produksi tahu di Wilayah Kecamatan Pekalongan sebesar Rp 283200.

2) Asal modal yang digunakan pada proses produksi tahu di Wilayah Kecamatan Pekalongan $100 \%$ berasal dari modal sendiri

3) Rata-rata bahan mentah ( kedelai) yang digunakan pada satu kali proses produksi tahu di Wilayah Kecamatan Pekalongan adalah $32,96 \mathrm{Kg}$ atau dibulatkan $33 \mathrm{Kg}$.

4) Bahan mentah yang digunakan pada proses produksi tahu di Wilayah Kecamatan Pekalongan berasal dari pembeliam di Pasar Pekalongan dan di Pasar Kota Metro

5) Rata-rata jumlah tenaga kerja yang digunakan pada proses produksi tahu di Wilayah Kecamatan Pekalongan adalah 2 (dua orang)

6) Asal tenaga kerja yang digunakan pada proses produksi tahu di Wilayah Kecamatan Pekalongan 72,13\% berasal dari dalam keluarga pengusaha tahu

7) Rata-rata pengeluaran untuk pembelian bahan bakar kayu dan solar yang digunakan untuk proses produksi tahu sebulan di Wilayah Kecamatan Pekalongan sebesar Rp 748800.

8) Bahan bakar kayu yang digunakan untuk proses produksi tahu berasal dari Desa Sidodadi dan sekitarnya, Pekalongan , Adijaya, dan Tulusrejo. Pembelian bahan bakar solar yang digunakan untuk proses produksi tahu berasal dari Pertamina dan Warung desa setempat.

9) Rata-rata produksi tahu setiap satu kali produksi di wilayah Kecamatan Pekalongan sebanyak 938 buah

10) Jenis transportasi yang digunakan untuk mengangkut kedelai adalah mobil truk dan sepeda motor. Transportasi untuk memasarkan produksi tahu di Kecamatan Pekalongan adalaah dengan sepeda motor

11) Sistem pemasaran produksi tahu di Wilayah Kecamatan Pekalongan adalah dijual sendiri oleh pengusaha dan dibeli oleh pedagang. Daerah pemasaran produksi tahu di Kecamatan Pekalongan adalah di pasar Kecamatan Pekalongan dan di Pasar Kota Metro

12) Rata-rata pendapatan perbulan industri tahu di Wilayah Kecamatan Pekalongan adalah sebesar Rp 1799600.

\section{Daftar Rujukan}

Bintarto, R. 1977. Buku Penuntun Geografi Sosial. Cetakan kedua. Yogyakarta: UP. Spring.

Bintarto, R., dan Hadisumarno, S.1987. Metode Analisa Geografi. Jakarta: LP3ES.

Daldjoeni. 1992. Geografi Baru Organisasi Keruangan Dalam Teori dan Praktek. Bandung: Alumni.

Johnston, R. J. 1981. The Dictionary of Human Geography. England: Blackwell Reference, Oxford. 
Kartasapoetra, R.G. 1987. Pembentukan

Perusahaan Industri. Jakarta:

Bina Aksara.

Nursid Sumaatmadja. 1988. Studi Geografi Suatu Pendekatan dan Analisa Keruangan. Bandung: Alumni

Nazir. 1999. Metode Penelitian. Jakarta: Ghalia Indonesia.

Rahardjo, Dawam. 1986. Transformasi Pertanian, Industrialisasi dan Kesempatan Kerja. Jakarta: UI Press. 